\title{
De-judicialization, Outsourced Review and All-too-flexible Bureaucracies in South African Land Restitution
}

\author{
Olaf Zenker, Institute of Social and Cultural Anthropology, Freie Universität \\ Berlin
}

\begin{abstract}
This article takes as its starting point a peculiar land claim within the ongoing South African land restitution process - more specifically, the legal and administrative technicalities that allowed for the implosion of the accompanying court case in the Land Claims Court - to open up a space for reflection on the ambiguous nature of state bureaucracies as ambiguity-reducing machines. Tracing the specificities of bureaucratic attempts at foreclosing ambiguities and insufficiencies in state practice, I show how a reorientation towards the new public goods of 'service delivery', 'transparency' and 'accountability' brought about a pronounced regime of performance indicators and de-judicialized bureaucratic flexibility. Demonstrating how these attempts to reduce ambiguities created new zones of ambiguity and unaccountability of their own, I argue for a post-Weberian analysis of the path-dependent realities of 'bureaucratic authority' to help us understand the seemingly arbitrary structural violence that state bureaucracies often enact.
\end{abstract}

Keywords: accountability, ambiguity, land claims, law, performance indicator, postWeberianism, South Africa, state

\section{The Opening of a Trial That Wasn't}

At around 9.45 on the morning of Monday 20 February 2012, I arrived at the Land Claims Court in Randburg, South Africa. As so often before, I had driven to this Johannesburg suburb to participate in court proceedings pertaining to the ongoing South African land restitution process. Restitution is an exemplary site where the moral modernity of the new South African state has been contested, renegotiated and made (see Zenker 2012; Zenker forthcoming a, b and c). Over the course of fourteen months of fieldwork conducted between 2010 and 2013, I traced land restitution within and between various state institutions (like this court), focusing on four exemplary claim settings all related to the former homeland KwaNdebele.

On this morning I was quite excited because this was to be the first day of a long trial, scheduled to last two weeks, concerning a large restitution case, and I was looking 
forward to getting into the details of both the legal procedures and the contested facts of this particular case. My anticipation was further fuelled by the fact that I had come to the Land Claims Court with similar prospects on so many prior occasions, only then to observe how the parties swiftly settled outside court within hours, typically in favour of the current (white) landowners opposing the claim. As I was about to learn, the situation would not be very different on this Monday morning.

Upon entering the building and greeting the members of staff I had become so well acquainted with, I learned that the legal representatives of the parties were already busy negotiating in Courtroom 2, while the presiding judge was still in his chambers waiting for the parties to come forward. I decided to go to see the judge, who was in the company of his assessor (an advisor appointed in restitution matters on a case-by-case basis), who - on this occasion - was a former Chief Land Claims Commissioner and professional advocate. We sat down and chatted, and the judge summarized the day's case for me. The trial, he explained, was to deal with the merits of the claim - that is, with the validity of the plaintiffs' claim to a right to restitution, which was contested by the current landowners. The Baphalane Ba Ramokoka community claimed to have been dispossessed of their rights to a large area of land - all in all, seventy-six portions of more than twenty farms situated near Rustenburg in the North West Province. This dispossession, the community claimed, satisfied the legal requirements for restitution according to post-apartheid law (see below), and hence entitled its members to restoration of the land. This claim was opposed by the Atlanta Northam Land Claim Action Committee, formed by a group of seventy-three affected white landowners.

After l eaving the $\mathrm{j}$ udge's $\mathrm{c}$ hambers, I w ent to C ourtroom 2, w here the l egal representatives of the various parties were busy discussing among themselves, working on a laptop or skimming through documents. In the gallery I counted twelve people (all clients, as I learnt), of whom it appeared only one was a member of the claimant community, while the other eleven were most likely members of the landowner committee. I greeted and briefly chatted with the lawyers of the different parties, most of whom I knew quite well through my earlier participant observation in court. Around 11.30, the lawyers of the claimants, the Minister of Land Affairs, and the Land Claims Commission came in and handed over to the landowners' lawyers a draft agreement on a USB stick. All of the lawyers present then gathered around a laptop and started negotiating the contents of this draft, amending it in accordance with their decisions. Once all were satisfied, the legal $r$ epresentatives of the landowners discussed the terms of the draft with their client representatives in the gallery. After the clients had consented to it as well, several printouts of the draft were made, one of which was then handed over to the judge and the assessor to scrutinize while all lawyers and clients waited in the courtroom.

After a short time, the door to the bench opened. The usher came in and announced, 'All rise! I call case number LCC 09 2007'. Everyone stood up as the judge and the assessor entered the bench. After all had sat down, the advocates, first of the plaintiffs and then of the defendants, stood up and formally introduced themselves. The judge then noted that, as the second judge was not yet present, there was not a full bench. It was agreed that section 28(8) of the Restitution Act (see below) still allowed the court to proceed, and that the order to be sent out should be signed by both judges. The judge 
then abruptly declared: 'This draft order is made an order of court!' He subsequently went on to commend the parties for managing to settle, stating: 'One must not settle always, but if the matter is settle-able, then one should settle! The Court adjourns'. The usher again gave the 'All rise' command as the judge and the assessor exited the courtroom.

It was only after saying goodbye to everyone that I found the time to think about how, surprisingly, the contested merits of this claim could have been settled so quickly. Among the various provisions within the order, four issues seem most important: first, that the 'plaintiffs abandon their land claims for physical restoration against properties' of the 'land owner defendants', who 'are hereby released from the further proceedings

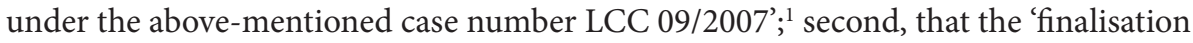
of the plaintiffs' restitution claims and in particular entitlement to [sic] of the plaintiffs to equitable redress, shall be subject to negotiation between the plaintiffs and the first defendant [i.e., the Minister of Land Affairs], through the Commission [on Restitution of Land Claims], failing which, the decision of the Court'; ' third, that 'the plaintiffs have indicated their desire to negotiate the purchase of some of the farms previously under claim'; ${ }^{3}$ and fourth, that the Minister and the Commission are ordered 'jointly and severally' to pay virtually all legal costs of the landowners, albeit on the lower 'scale as between party and party', including their lawyers' 'reservation fees for the first four days of the trial', originally scheduled for ten days but which had just ended so prematurely. ${ }^{4}$

Now, how is one to make sense of this astonishing agreement in which the claimants, before even arguing their case, suddenly rescinded their demand for the restoration of the land? After all, if they were indeed entitled to restitution, as they continued to insist through their sudden demand for 'equitable redress', they had every right to press their claim against the will of the current owners, ${ }^{5}$ a claim that they had already been pursuing through legal channels for the previous five years. How is one to relate the outcome of such legal proceedings to the new state's attempt to right the historical wrongs of colonial land dispossession? And, finally, in what ways does such 'a trial that wasn't' open up a space for reflection on the diverse processes and intricacies, the possible profits and pitfalls, of more flexible bureaucracies built on 'new public goods'?

In the pursuit of answers to these questions, I will first engage with the remarkable transformation of what, during the anti-apartheid struggle, was a highly politicized land question into a strictly juridified and judicialized field of state proceedings in the new era. This will provide some necessary background information for understanding more clearly how this trial (that wasn't) was made possible in the first place. I will then show how the low annual rates of settling land claims during the new restitution programme's first five years led to a state reorientation towards 'new public goods' such as service delivery, transparency and accountability. This was mainly achieved through a de-judicialization of restitution, on the one hand, and an increasing use of land claim settlement statistics as indicators of state performance, on the other. Although this has indeed led to a remarkable increase in measurable public performance, with settlement rates accelerating rapidly, this process of making the administrative bureaucracy more flexible has simultaneously freed it substantially from systematic judicial review. I will then focus on the inadvertent absurdities that such a reduction (or, as we will see, outsourcing) of review has made possible - not least in missing the opportunity that 
our trial would have afforded to publicly review both the merits of the claim and the quality of state officials' work. I will conclude with some reflections on the implications of attempts like these to establish more flexible bureaucracies based on 'new public goods' for the closure of bureaucratic ambiguity.

\section{The Juridification and Judicialization of 'the Land Question' at the End of Apartheid}

Colonialism in South Africa was, at its core, crucially intertwined with state laws controlling access to land. While divergent provincial regulations had existed before, since the Natives Land Act (Act 27 of 1913) a plethora of countrywide legislative acts increasingly restricted black people's land rights, ${ }^{6}$ thereby legalizing their massive dispossession, and circumscribed their movement in space. The racial segregation that ensued had enormous consequences, limiting their civil and political rights, curbing their access to resources, labour and capital, and severely constraining their social and cultural lives.

It is therefore not surprising that the history of race-based land dispossession persistently occupied a prominent position in the struggle against colonialism (Walker 2008: 50-51). For decades, anti-apartheid activists protested, fought legally and documented the race-based dispossession of land and forced removals involving an estimated 3.5 million black people between 1960 and 1983 alone (Abel 1995: 385-522; Platzky and Walker 1985: 10). The Freedom Charter, officially adopted by the Congress of the People in 1955, demanded that 'all the land [shall be] re-divided amongst those who work it' (African National Congress [ANC] 2011); this document continued to inspire the struggle for democratization for decades to come. Thus when apartheid was nearing its end in the late 1980s, many ANC activists assumed that a key priority of any future land reform would be a politically endorsed nationalization of existing land holdings (Klug 2000: 125) - and it is a demand that flares up in popular discourses in South Africa to the present day. It was therefore not at all clear at the beginning of the transitional negotiations in the early 1990s that one of the central aims of the liberation movement - to bring about equitable access to land through the restitution of dispossessed lands to their original owners - would ultimately rely on a strictly juridified approach under the rule of law.

Blichner and Molander (2008) offer a helpful discussion of 'juridification', identifying five distinct dimensions: (1) constitutive juridification, which refers to the expansion of a whole legal order, for instance through a formal constitution; (2) juridification as the expansion of law into hitherto unregulated domains; (3) juridification as increased conflict resolution with reference to law (in and beyond courts); (4) juridification as the increased power of the judiciary; and (5) juridification as the legal framing of subjectivities. As it so happened, the South African transitional negotiations, dominated by the ruling white supremacist National Party (NP) and the ANC, ended up thoroughly juridifying 'the land question' in terms of the first four dimensions (and, in the long run, also in the fifth). Walker (2008: 51-69) describes in detail how this development came about. She shows that, for senior ANC members, nationalization of land looked less and less like 
a viable option, given the negative experiences with state farms in socialist countries, fears about the destruction of commercial agriculture, growing pressure from local and transnational capital in favour of market-based land reform, the spectre of ensuing capital flight, and a general political moderation of the ANC in its attempt to win consensual endorsement. Against this backdrop, enshrining existing land rights and land reform into the new constitutional bill of rights developed into a matter of strategic compromise - especially as the still ruling National Party strongly insisted on safeguarding property rights, particularly concerning agricultural land (Walker 2008: 54). Eventually, this brought about the current Constitution of the Republic of South Africa (Act 108 of 1996), which protects both property rights and the right to redress for racially based violations of past property rights (Klug 2000: 124-136; Walker 2008: 50-69).

In this process, the politicized land question - and land restitution in particular - became profoundly juridified, first through constitutive juridification (dimension 1), with the new Constitution for all South Africans now explicitly stipulating in section 25(7) that a person or community dispossessed of property as a result of past racially discriminatory laws or practices is entitled, to the extent provided by an act of Parliament, either to land restoration or to equitable redress. The hitherto unregulated domain of how to restore land to its former owners became subsequently juridified as well (dimension 2), when the act of Parliament in question - the Restitution of Land Rights Act (Act 22 of 1994) - defined the legal framework for the restitution process and established the Commission on Restitution of Land Rights and the specialist Land Claims Court as its key players. The Act further provided a set of criteria according to which claimants are either entitled to 'land restoration' or 'equitable redress': the claimant can be an individual or a community (whose land rights were derived from shared rules determining access to land held in common); the claimant must have been dispossessed of a right to land after 19 June $1913^{7}$ on the basis of racially discriminatory laws and practices; and finally, claimants must not have received just and equitable compensation - and (originally) had to lodge their claims before 31 December 1998. ${ }^{8}$ Significantly, the right in land to be restituted was explicitly not limited to former freehold ownership, but was defined much more broadly. ${ }^{9}$

Under this specific rule of law, the Act construed 'the state' as simultaneously functioning as the core reference point (as claims are lodged against the state, i.e., the Minister of Land Affairs), the champion of claimants through the Commission on Restitution of Land Rights (under the same minister) and the judicial arbiter through the Land Claims Court (under the Minister of Justice). Within this setting, once Commission officials verified the validity of a claim, they were tasked with aiming for a settlement agreement between claimants and (usually white) landowners, whereby the state would buy the land and, based on certain conditions, hand it over to the claimants. With or without such an agreement, however, each of the approximately 80,000 claims lodged initially had to be referred to the Land Claims Court for final settlement. This meant that land restitution was further juridified in the sense that each case had to be ultimately resolved in court with reference to law (dimension 3), thus giving the final say and substantial power to judicial review (dimension 4). This dual juridifying process of empowering courts is often more specifically referred to in terms of 'judicialisation' (Blichner and Molander 2008: 45). 
In this remarkable juridification and judicialization of the formerly politicized issue of 'the land', South Africa is not unique. In recent decades there has been a massive increase worldwide in constitutionalism, faith in the judiciary and 'the rule of law', with more than one hundred constitutions (re)written since 1989 (Comaroff and Comaroff 2006: 22; see also Klug 2000; Tamanaha 2004). Globally, as John and Jean Comaroff (2006: 26) observe, a 'judicialization of politics' is taking place, in which '[p]olitics itself is migrating to the courts', although this 'fetishism of the law', as they put it, often amounts to little more than 'lawfare - the resort to legal instruments, to the violence inherent in the law, to commit acts of political coercion' (Comaroff and Comaroff 2006: 26, 22, 30; see also Randeria 2007). Such globally circulating patterns of juridification - possibly, but not necessarily repressive in their effects (see Eckert et al. 2012a, 2012b; Zenker 2012) - have indeed broadly shaped the emergence of South African land restitution as a legal process. However, for current purposes it seems more important to highlight that restitution, while still principally juridified, subsequently experienced a marked dejudicialization that has had profound consequences for its future operations.

\section{The New Public Goods of South African Land Restitution and the Shift Towards De-judicialization and Indicatorization}

When the Commission on Restitution of Land Rights took up its work in early 1995, the then Minister of Land Affairs, D erek Hanekom, declared that the work of the Commission would be finished in three years (Walker 2008: 8). In its 1997 White Paper on South African Land Policy however, the Department of Land Affairs had to shift its deadlines for the restitution process, providing for a three-year period for the lodging of claims, a five-year period for the Commission and the Court to finalize all claims and a ten-year period for the implementation of all court orders (Department of Land Affairs 1997: para 4.13). Yet these and subsequent deadlines for finalizing all claims proved elusive again and again. At the time of writing (in 2014), the (original) restitution process had still not been completed, while the period for lodging land claims was recently reopened and extended until 30 June 2019 (see endnote 8).

Although the institutional triad of the Land Claims Court (LCC), the Commission and the Department of Land Affairs (DLA) ${ }^{10} \mathrm{~h}$ ad been principally laid out in the Restitution Act (see above), the somewhat ambiguous competencies of each body soon led to tensions, to the detriment mainly of the Commission. On the one hand, frictions arose from the fact that the Commission seemed to be institutionally independent of the DLA, while the latter's de facto mandate was, according to Walker (2008: 6), 'to fund, staff and resource the Commission, represent the interests of the state (against whom all claims were lodged) in the negotiations process, and manage the implementation of restitution settlements', since the responsibility of the overarching land reform programme, incorporating restitution, lay (and still lies) with the Minister of Land Affairs. On the other hand, the power of the Commission - already obliged to refer settlement agreements to the LCC to make them court orders - was further curtailed by subsequent case law in which the LCC not only made use of its exclusive jurisdiction to review and alter Commission decisions, but further specified that the role of the Commission was merely 'an investigative and facilitatory one' (Tong 2007: 38). 
Within this set-up, the actual process of settling land claims proved frustratingly slow: in 1997, the very first claim was settled by the Court, and it remained the only one for that entire year; in 1998, the total number of settled claims rose to seven, climbing to a total of forty-one in 1999. This was an intolerably low settlement rate, given that about 80,000 claims awaited their finalization in the file storage rooms of the Commission. Against this backdrop, the Minister of Land Affairs ordered a review in 1998, leading to marked changes in the restitution process, including amendments of the Restitution Act that transformed the formerly judicialized into the current administrative process: now the Minister of Land Affairs, and by delegation the Land Claims Commissioners, have the power to facilitate and conclude settlements by agreement, and only claims that cannot be resolved this way take the judicial route through the Land Claims Court. Furthermore, in 1999 the Commission became closely integrated into the DLA, and both the Chief Land Claims Commissioner and the Minister of Land Affairs were replaced by the new President Mbeki, leading to a major exodus of senior staff in the Department of Land Affairs in 1999-2000 (James 2007: 36-40; Walker 2008: 12-14; Zenker 2015).

This de-judicialization in the late 1990s took place in the increasingly globalized context of neoliberal discourses and public policy orientations captured by the imagery of 'new public goods' such as efficiency, flexibility, transparency, accountability, databased monitoring and evaluation within an overarching 'audit culture' (Power 1997; Strathern 2000). In fact, the strong emphasis on more pragmatism, realism and efficient state performance in land reform generally, which emerged in 1999 under the new Mbeki administration, can be seen as part of a broader shift of this government towards more explicitly neoliberal policies (James 2007: 40, 32). Under these circumstances, the de-judicialization of the restitution process, as described above, was evidently deemed a crucial strategy in order to bring about such new public goods.

Another strategy in the service of more efficient public 'service delivery', also emerging around that time, consisted in increasingly treating numbers and land claim settlement statistics as indicators of state performance. ${ }^{11}$ In 1997 the White Paper on South African Land Policy already referred abstractly to the need to develop 'service standards with clearly defined outputs, targets and performance indicators' (Department of Land Affairs 1997: para 6.5.2). However, it was only through the Mbeki administration's strong emphasis on drastically speeding up the restitution process that settlement statistics, such as annual settlement rates, were consciously transformed into explicit indicators of state performance. This deliberate use of numbers to measure the new public good of efficiency has also transformed the state's rhetoric of transparency and accountability: in recent years, it has become standard procedure within the DLA and the Commission to publicly refer to the numbers of claims settled in terms of 'output performance measures' and 'indicators', and to use these figures to measure retrospectively actual performance against target performance (see, for example, Commission on Restitution of Land Rights 2012: 13). All in all, this has led to a situation in which ' $[\mathrm{g}]$ overnment and public opinion have mainly measured the achievements of restitution quantitatively in terms of the number of claims settled and people who have benefitted, and the extent of land restored to claimants' (Hall 2010: 28). 
The combined e fforts of tu rning the DL A (i ncorporating th e Co mmission), through de-judicialization, into a more flexible bureaucracy, while simultaneously pressing for efficient service delivery through transforming settlement statistics into 'transparent' and 'publicly accountable' indicators of state performance, apparently bore fruit: between March 1999 and March 2007, the annual rate of settling claims moved between a minimum of 2,772 claims (in 2006/7) and an impressive maximum of 17,783 (in 2001/2), adding up to a total of 74,417 claims reported as 'settled' in March 2007, that is, 93.38 per cent of the total of 79,696 claims lodged. In that year, the Commission also reported that it was 'entering the most difficult part of the restitution process', since it was now only left with outstanding rural claims that were often very complex and quite difficult to resolve (Commission on Restitution of Land Rights 2007: 3). Correspondingly, the rates again substantially decreased to only a reported few hundred claims settled per year since 2007. Nevertheless, the total number of only 3,673 outstanding claims, as reported in March 2011, seems to point to considerable success in getting South African land restitution to benefit from 'the new public goods.' ${ }^{12}$

\section{Outsourced Review and (all too) Flexible Bureaucracies}

The story of this apparent success by the numbers is, of course, not that straightforward. As I have analysed elsewhere, worrying inconsistencies regarding the published statistics have been noted and have even been publicly acknowledged by the DLA (Zenker forthcoming b). Furthermore, the problem of quantification leaving out so much of the marked specificity of each land claim highlights the profound ambiguity involved in comparing and counting as 'settled' completely different cases and settings (ibid.). Finally, the use of quantifiable indicators to measure success - a process I shall refer to by the somewhat ungainly term 'indicatorization' - has developed a social life of its own, producing various unintended consequences with, in fact, adverse effects on the finalization of the land restitution process (ibid.). These and other problems related to indicatorization have been rightfully criticized (Walker 2008; see also Walker 2012), highlighting the need to get a grip on the unintended consequences of indicatorization, improve the quality of national statistics and provide more adequate resources for meaningfully finalizing all claims.

Yet such criticism is unlikely to change substantially the importance of settlement statistics as 'boundary objects' (Star and Griesemer 1989: 393) linking the local arena of individual claims with the national arena of public accountability. As such, I argue that these numbers allow land restitution to be processed in the local arena of individual injustices and private interests, as well as in the national arena of public accountability and new public goods, thus enabling 'the state' to translate, and hence balance, divergent interests and concerns (see Zenker forthcoming b). In recent years, rather than continuing to privilege the private interests of a lucky few, indicatorization has tipped this balance in restitution towards a stronger emphasis on public interests, which insist that relative justice is given to all claimants in a justifiable time span and that public funds are spent in a cost-efficient way.While the strategy of indicatorization thus has to some extent increased public accountability of the restitution process, ironically its partner strategy, de- 
judicialization, has simultaneously undermined such accountability in profound ways. This is so because the now de-judicialized Restitution Act concentrates substantial powers in the hands of the Minister of Land Affairs (and, by delegation, the DLA, incorporating the Commission), while simultaneously freeing him/her substantially from systematic judicial review. The Minister may now enter into an agreement with all interested parties, which crucially include, on the one hand, the current landowners and, on the other, in the final analysis only the Minister him- or herself - the Janusfaced representative of both the Commission as the champion of the claimants and 'the state' against which all claims are lodged. In other words, given that the current owners are evidently not opposing the claim - otherwise there could be no agreement in the first place - the Ministry is effectively left to its own devices to decide on the validity of the claim without any external review. Correspondingly, this setting implies that any judicial review through the Land Claims Court only comes into existence when an interested party - usually the current landowners, but sometimes also the claimants ${ }^{13}$ oppose the decisions of the Minister, the DLA or the Commission. Only then does the Court enter the restitution process or, more to the point, only then must the restitution process enter the Court for independent review. In effect, this means that the function of ensuring any judicial review of the restitution work by the administrative state is outsourced to private interested parties - and in the case of current landowner, usually at their own cost, as cost orders in restitution are rare (more on that below).

This outsourcing of judicial review has turned the administrative state of restitution into an all-too-flexible bureaucracy, confronted with the constant temptation to act with impunity when dealing with unopposed land claims. But the administrative bureaucracy is endowed with still greater flexibility, and thus faces greater temptations, in cases that actually are contested. Given that land claims are lodged against the state and not against current landowners, the latter become interested parties only if a valid claim is made for 'land restoration' rather than 'equitable redress' (for example, financial compensation). Thus, although a valid claim in principle entitles a claimant equally to land restoration or equitable redress (as long as restoration is feasible), the current landowners only become affected if the reparation sought consists of the actual land. This has profound consequences because, in court cases involving opposing landowners, the Minister of Land Affairs, as representative of the Commission, has already agreed that the claim is valid (otherwise there would be no court case), whereas the same Minister, as the first defendant representing 'the state', does not oppose his or her own decision about the validity of the claim. Thus the dispute usually lies only with the landowners; if they can be removed from the proceedings, then the court case collapses. This is easily achieved, of course, if the claimants decide no longer to claim 'land restoration' but rather 'equitable redress'. In that case, the whole matter turns into an affair of mutual consent between claimants and, in the last instance, the Minister (as both claimants' champion and the target of their legal demands) - a 'tryst with destiny' that is neither disturbed nor confronted by current landowners, judges or any other sceptical member of the public.

Against this background, the openings of the trial-that-wasn't evoked in this text can be seen in a new light. Needless to say, the 'true' reasons for the court interactions described above remain forever shrouded in mystery. But as an illustration of the ways 
in which the new public good of 'publicly accountable service delivery' in South African land restitution has produced its own zones of potential unaccountability, this case might actually work as a useful exemplar. In this spirit, let us have a closer look at the technicalities of this court order. Of the four important issues in the order mentioned at the beginning of this text, the first and the second point illustrate that the de-judicialized set-up of restitution indeed allows abandoning a 'land claim for physical restoration', so that the 'land owner defendants' are 'hereby released from the further proceedings', leaving the 'finalization of the plaintiffs' restitution claims and in particular entitlement ... to equitable redress ... to negotiation between the plaintiffs and the first defendant [i.e., the Minister of Land Affairs], through the Commission. While in the course of such negotiations, the Minister might theoretically find against such an entitlement - always allowing the legal possibility, as the order emphasizes, that a future disagreement between claimants and the Ministry might again necessitate 'the decision of the Court' - such a development is rather unlikely. This is because the Ministry had already committed itself thoroughly to the validity of the claim; otherwise there would not have been a court case in the first place. De-judicialized restitution hence provides unaccountable spaces for covering up not only invalid claims but also, and more to the point, improper behaviour by the administration. This is particularly tragic in cases where claimants actually $d o$ have a valid claim but, due to inadequate research and the sloppy work of state officials, end up being forced to rescind their claim to 'land restoration' and to settle, as a last resort in order to get at least some compensation, through 'equitable redress', which is usually of much lower monetary value.

When viewed from this angle, the third point of the court order becomes quite interesting: evidently, rightful claimants may ask for either land restoration (if feasible) or equitable redress, and they may, of course, change their demands in the course of legal proceedings. Perhaps claimants such as those referred to in the opening case simply preferred monetary compensation over land? But then why would they still formally indicate 'their desire to negotiate the purchase of some of the farms previously under claim'?

It remains to consider the last of the four points, namely that the Minister and the Commission were ordered to pay basically all legal costs of the landowners, if only on the lower 'scale as between party and party'. Here it is crucial to emphasize that, unlike in other legal proceedings, cost orders in South Africa land restitution are actually quite rare. ${ }^{14}$ The Land Claims Court, as a court of equity, has the discretion 'to make orders for costs as it deems just, including an order for costs against the State or the Commission. ${ }^{15}$ Thus far, the precedent has been that the LCC only grants cost orders against the state either at the lower scale as between party and party or as punitive cost orders at the higher scale as between attorney and client if the bench is convinced that the state profoundly misbehaved. Seen in this light, it seems rational for the administrative state to voluntarily include a cost order against itself (albeit at lower scale), only if it fears that, should the court case proceed, the opposing party would reveal profound misbehaviour on the part of the state, leading to a cost order anyway.

While it is impossible to say, and ultimately immaterial, whether the line of reasoning sketched out here was also part of the motivation behind the collapse of the trial in the Baphalane Ba Ramokoka community claim, this overall analysis opens up a 
space for reflection concerning the intricacies of modern rational-legal 'states at work' (Bierschenk and Olivier de Sardan 2014) and, more specifically, the possible profits and pitfalls of flexible bureaucracies built on the edifice of new public goods.

\section{Closing in on Closures of Bureaucratic Ambiguity}

In their recent attempt at 'rethinking the state', Migdal and Schlichte (2005) propose what they call a post-Weberian conception of the state, describing it as a field of power characterized by dialectics between 'the image' of a unitary, territorially bounded, supreme law-making organization with compulsive membership that claims a monopoly on legitimate violence and representation of the people, and the enormously variable 'actual practices' realized in ostensible orientation towards such an image, involving those officially empowered by such representation and those they engage in their roles as 'officials' (see esp. Migdal and Schlichte 2005: 15). This approach - which finds echoes in Sharma and Gupta's (2006) suggestion to investigate everyday practices and representations of the state - insists on treating the Weberian ideal-type of the state as precisely this: an idea and ideal that informs not only social research, but equally functions as one meaningful orientation, alongside others, for practices within and beyond actually existing 'states' (see Migdal and Schlichte 2005: 10-11). In this sense, it becomes possible also to investigate Weberian 'bureaucratic authority' - that is, the ideal-type characterizing rational-legal modern statehood, with its belief in the legality of enacted rules, domination through knowledge and an emphasis on circumscribed, rule-bound jurisdiction, office hierarchy, file keeping and expert training, as well as officialdom as a full-time profession (Weber 1978: 56, 215-226, 956-1005) - less as an adequate model of reality and more with regard to the multiple realities of this model in actors' thoughts and practices.

Interrelated clusters of actors that profess to orientate their practices principally towards such an image of 'rational-legal modern statehood' and are socially recognized as acting in its name - in other words, actually existing state bureaucracies - are often perceived as 'ambiguity-reducing machines', organizing their technical knowledge through classification, standardization, quantification and routine (Best 2012: 91-92; see also Handelman 2004: 19-41; Scott 1998: 11-83). Ambiguity constitutes a form of indeterminacy, referring to 'the polyvalence of social life' and 'the inescapability of interpretation' (Best 2008: 356). As such, it represents a core problem for bureaucracies, leading to the strategies for ambiguity reduction mentioned above. However, as Best (2012: 91-93) points out, too forceful a reduction of ambiguity in the workings of bureaucracies may equally hamper their responsiveness in the light of always-given uncertainties, diversities and limits to quantification and indicatorization (as discussed above). Hence, there are also incentives for bureaucracies to foster at least some ambiguity in order to use it as a strategic asset for governing (Best 2008: 356).

In addition to identifying a broad empirical spectrum of ambiguities, ranging from deliberately reduced to actively fostered forms, Best (2012) insists that despite clever mechanisms for reducing the ambiguities of social interaction, they tend to persist, not least because the very efforts to constrain such ambiguities inevitably create new ones. In other words, besides empirically variable ambiguities, 'residual ambiguities' 
that exceed our controlling efforts also exist (ibid.: 88-91). In this sense, ambiguity can be summarized as impacting on the actual work of bureaucracies in three ways: as an object of governance fundamentally in need of rule-bound control; as a strategic asset for governance, creating room for discretion; and as a principal and inevitable limit to any governance (Best 2008).

Lipsky's (2010) seminal work on the dilemmas of the individual in public service might help shed further light on the possible interrelations between these three forms of bureaucratic ambiguity. Lipsky focuses on a category of state officials that he calls 'street-level bureaucrats', characterized both by direct interaction with citizens as clients of public services and by their 'substantial discretion in the execution of their work' (Lipsky 2010:3). He argues that notoriously limited resources, conflicting goals of their agencies, the concomitant absence of clear performance measures and highly complex situations on the ground lead to situations in which street-level bureaucrats - such as restitution officials within the South African administration - have relative autonomy from organizational authority and exercise wide discretion. One of Lipsky's central theses is that this state of affairs de facto turns the day-to-day actions of street-level bureaucrats - and not their agency's official statements - into the ultimate determinant of state policies (Lipsky 2010: 13-25). Summarizing Lipsky's observations in terms of bureaucratic ambiguity, one might say that in the foundational attempt to control ambiguity as an object of governance through establishing and following explicit rules - that is, in orienting state action towards 'bureaucratic authority' - and given the inevitable presence of residual ambiguity that is beyond control, new ambiguity is produced allowing officials discretion both in 'applying' rules differently and in hiding behind a façade of indifference (see Herzfeld 1992).

Arguably, a similar mechanism has been at play within the shift in South African land restitution towards more flexible bureaucracies based on new public goods. The attempt to govern ambiguities in the early restitution process produced an imbalanced preference for the private interests of a chosen few at the expense of all other claimants and public interests more generally. This led to new public goods such as service delivery, transparency and accountability being evoked as corrective bureaucratic measures. However, given the polyvalence of social life and hence residual ambiguity, the newly produced, more flexible bureaucracies have entailed their own ambiguities: on the one hand, land restitution has profited greatly in terms of a drastically accelerated settlement process and some increase of public accountability through indicatorization. But on the other hand, the de-judicialization that was deemed necessary to make possible this more efficient service delivery has created profound pitfalls of unaccountability for a process ostensibly oriented towards the image of the modern rational-legal state. It has provided the means for possibly shielding an overburdened and partly incapable bureaucracy against external review and judicial scrutiny, and has thereby both jeopardized the restoration of land to rightful claimants and allowed for the abuse of public funds.

This mechanism of de facto production of new bureaucratic ambiguities through the attempt to reduce such ambiguities, given the inescapably ambiguous nature of the only means of closure at hand, leads recursively to an infinite regress that is at the heart of the constant metamorphosis of 'the modern state. This does not mean, of 
course, that since bureaucratic ambiguity is inescapably in excess, new public goods are merely old goods in new stately bottles: plus ça change, plus c'est la même chose. On the contrary, it is in tracing the path-dependent, historically situated specificities of attempted bureaucratic closures of ambiguity that it becomes possible to close in on some of the reasons behind often peculiar state actions which - as Gupta (2012) points out - in their structural violence otherwise appear as nothing but arbitrary.

\section{Acknowledgements}

This text is based on research that was financially supported by an Ambizione Research Fellowship of the Swiss National Science Foundation and by the Berne University Research Foundation. I am grateful for critical engagements by Laura Bear, Peter Brett, Jorge Campos Tellez, Jean and John Comaroff, Lauren Coyle, Brian Donahoe, Julia Eckert, Deborah James, Nayanika Mathur, Pauline Peters and Stefan Salomon, as well as the participants of the Harvard African Studies Workshop, where an earlier version was presented in September 2013.

\section{Notes}

1. See 20120220 Baphalane ba Ramokoka Community and Others v Minister of Agriculture and Land Affairs and Others (LCC 09/2007, unreported), sections 1 and 5.

2. See 20120220 Baphalane ba Ramokoka Community and Others v Minister of Agriculture and Land Affairs and Others (LCC 09/2007, unreported), section 3.

3. See 20120220 Baphalane ba Ramokoka Community and Others v Minister of Agriculture and Land Affairs and Others (LCC 09/2007, unreported), section 9.

4. See 20120220 Baphalane ba Ramokoka Community and Others v Minister of Agriculture and Land Affairs and Others (LCC 09/2007, unreported), section 8.

5. It is a common misunderstanding in South African public opinion, unfortunately perpetuated within some of the academic literature (e.g., Hall 2010; Lahiff 2007), that land restitution - like land redistribution - is conducted under some kind of 'willing-buyer willing-seller' policy whereby 'the owners of the claimed property have an effective veto on land restoration' (Hall 2010: 25). This is not the case, as owners are merely entitled to just and equitable compensation as defined in section 25(3) of the Constitution, but cannot prevent land restoration if it is the remedy desired by rightful restitution claimants and deemed feasible by the state.

6. I use the conventional categories African, Indian, coloured, black (as inclusive of the previous three categories) and white to describe the different social groups that were identified as 'distinct' under the apartheid system, while acknowledging the dilemma that the inevitable usage of these socially constructed terms might reinforce their alleged 'reality' as biologically predetermined categories.

7. This was the day of the promulgation of the Natives Land Act, first legalizing massive dispossessions countrywide by introducing racial zones of possible landownership and by restricting black reserves to only 7 per cent of South African land (later to be extended to 13 per cent).

8. On 29 June 2014, President Jacob Zuma signed the Restitution of Land Rights Amendment Act (Act 15 of 2014), which reopened the period for lodging land restitution claims and extended it until 30 June 2019.

9. For a discussion of the implications of this broad definition for the evolution of property regimes, justice and social reconciliation in post-apartheid South Africa and its subsequent development in case law, see Zenker (2014).

10. The Department of Land Affairs (DLA) was officially renamed the Department of Rural Development and Land Reform in 2009. However, in order to avoid confusion, I continue to refer to it as the Department of Land Affairs or DLA in this text. 
11. For a detailed account of this indicatorization of South African land restitution, see Zenker (forthcoming b).

12. See Zenker (forthcoming b) for a compilation of annual settlement statistics published by the Commission on Restitution of Land Rights in its Annual Reports between 1996 and 2013.

13. This category of dissatisfied black claimants making use of their right to direct access to the Land Claims Court is very often also joined by white land claimants (see Zenker forthcoming c).

14. As claimant communities often qualify for legal aid, whereas current (white) landowners do not, the latter usually end up having to pay their own costs, which causes frustration and anger. As an opposing white landowner in another case that I have investigated put it, 'I had to pay my own lawyers, while the state was on the side of the claimants ... We had to prove out of our own pockets that it was our own land, for which we had title deeds and everything' (see Zenker 2014: 517). Understandable as this frustration might be with regard to individual tragedy, this situation reflects precisely the broader racialized political economy of South Africa that land restitution is meant to at least partly redress.

15. See Restitution of Land Rights Act (Act 22 of 1994), subsection 35(2)(g).

\section{References}

Abel, R.L. 1995. Politics by Other Means: Law in the Struggle against Apartheid, 1980-1994. New York: Routledge.

African National Congress (ANC). 2011. The Freedom Charter, as adopted at the Congress of the People, Kliptown, on 26 June 1955. Available at <http://www.anc.org.za/show.php?id=72> (accessed 3 January 2013).

Best, J. 2008. Ambiguity, Uncertainty, and Risk: Rethinking Indeterminacy. International Political Sociology 2: 355-374.

Best, J. 2012. Bureaucratic Ambiguity. Economy and Society 41(1): 84-106.

Bierschenk, T., \& J.-P. Olivier de Sardan (eds) 2014. States at Work: Dynamics of African Bureaucracies. Leiden: Brill.

Blichner, L.C., \& A. Molander. 2008. Mapping Juridification. European Law Journal 14(1): 36-54.

Comaroff, J.L., \& J. Comaroff. 2006. Law and Disorder in the Postcolony: An Introduction. In Law and Disorder in the Postcolony (eds) J. Comaroff and J.L. Comaroff, 1-56. Chicago: University of Chicago Press.

Commission on Restitution of Land Rights. 2007. Annual Report 2006/07. Pretoria: Department of Land Affairs.

Commission on Restitution of Land Rights. 2012. Annual Report 2011/12. Pretoria:

Department of Rural Development and Land Reform.

Department of Land Affairs. 1997. White Paper on South African Land Policy. Pretoria: Government Printers.

Eckert, J., Z.Ö. Biner, B. Donahoe \& C. Strümpell. 2012a. Law's Travels and Transformations. In Law against the State: Ethnographic Forays into Law's Transformations (eds) J. Eckert, B. Donahoe, C. Strümpell \& Z.Ö. Biner, 1-22. Cambridge: Cambridge University Press.

Eckert, J., B. Donahoe, C. Strümpell \& Z.Ö. Biner (eds) 2012b. Law against the State:

Ethnographic Forays into Law's Transformations. Cambridge: Cambridge University Press. Gupta, A. 2012. Red Tape: Bureaucracy, Structural Violence, and Poverty in India. Durham:

Duke University Press.

Hall, R. 2010. Reconciling the Past, Present, and Future: The Parameters and Practices of Land Restitution in South Africa. In Land, Memory, Reconstruction, and Justice: Perspectives on Land Claims in South Africa (eds) C. Walker, A. Bohlin, R. Hall \& T. Kepe, 17-40. Athens: Ohio University Press. 
Handelman, D. 2004. Nationalism and the Israeli State: Bureaucratic Logic in Public Events. Oxford: Berg.

Herzfeld, M. 1992. The Social Production of Indifference: Exploring the Symbolic Roots of Western Bureaucracy. New York: Berg.

James, D. 2007. Gaining Ground? 'Rights' and 'Property' in South African Land Reform. Abingdon: Routledge-Cavendish.

Klug, H. 2000. Constituting Democracy: Law, Globalism, and South Africa's Political Reconstruction. Cambridge: Cambridge University Press.

Lahiff, E. 2007. State, Market, or the Worst of Both? Experimenting with Market-Based Land Reform in South Africa. Occasional Paper No. 30. Bellville: Programme for Land and Agrarian Studies, University of the Western Cape.

Lipsky, M. 2010. Street-Level Bureaucracy: Dilemmas of the Individual in Public Services. New York: Russell Sage Foundation.

Migdal, J.S., \& K. Schlichte. 2005. Rethinking the State. In The Dynamics of States: The Formation and Crises of State Domination (ed.) K. Schlichte, 1-40. Aldershot: Ashgate.

Platzky, L., \& C. Walker. 1985. The Surplus People: Forced Removals in South Africa. Johannesburg: Ravan Press.

Power, M. 1997. The Audit Society: Rituals of Verification. Oxford: Oxford University Press.

Randeria, S. 2007. De-politicization of Democracy and Judicialization of Politics. Theory, Culture \& Society 24(4): 38-44.

Scott, J.C. 1998. Seeing Like a State: How Certain Schemes to Improve the Human Condition Have Failed. New Haven: Yale University Press.

Sharma, A., \& A. Gupta. 2006. Introduction: Rethinking Theories of the State in an Age of Globalization. In The Anthropology of the State: A Reader (eds) A. Sharma \& A. Gupta, 1-41. Malden: Blackwell.

Star, S.L., \& J.R. Griesemer. 1989. Institutional Ecology, 'Translations' and Boundary Objects: Amateurs and Professionals in Berkeley's Museum of Vertebrate Zoology, 1907-39. Social Studies of Science 19(3): 387-420.

Strathern, M. (ed.) 2000. Audit Cultures: Anthropological Studies in Accountability, Ethics and the Academy. London: Routledge.

Tamanaha, B.Z. 2004. On the Rule of Law: History, Politics, Theory. Cambridge: Cambridge University Press.

Tong, M. 2007. Jurisprudence on Restitution of Land Rights in South Africa: Lest We Forget. Pretoria: Department of Land Affairs/Commission on Restitution of Land Rights.

Walker, C. 2008. Landmarked: Land Claims and Land Restitution in South Africa. Athens: Ohio University Press.

Walker, C. 2012. Finite Land: Challenges Institutionalising Land Restitution in South Africa,, 1995-2000. Journal of Southern African Studies 38(4): 809-826.

Weber, M. 1978. Economy and Society: An Outline of Interpretive Sociology. Berkeley: University of California Press.

Zenker, O. 2012. The Juridification of Political Protest and the Politicisation of Legalism in South African Land Restitution. In Law against the State: Ethnographic Forays into Law's Transformations (eds) J. Eckert, B. Donahoe, C. Strümpell \& Z.Ö. Biner, 118-146. Cambridge: Cambridge University Press.

Zenker, O. 2014. New Law against an Old State: Land Restitution as a Transition to Justice in Post-Apartheid South Africa? Development and Change 45(3): 502-523.

Zenker, O. 2015. Politics by Other Means Revisited: Legal Activism and Land Reform in PostApartheid South Africa. Unpublished paper. 
Zenker, O. Forthcoming a. Bush-Level Bureaucrats in South African Land Restitution: Implementing State Law under Chiefly Rule. In The State and the Paradox of Customary Law in Africa (eds) O. Zenker \& M.V. Hoehne. Aldershot: Ashgate.

Zenker, O. Forthcoming b. Failure by the Numbers? Settlement Statistics as Indicators of State Performance in South African Land Restitution. In A World of Indicators: The Making of Governmental Knowledge through Quantification (eds) R. Rottenburg, S.E. Merry, S.-J. Park \& J. Mugler. Cambridge: Cambridge University Press.

Zenker, O. Forthcoming c. South African Land Restitution, White Claimants and the Fateful Frontier of Former Kwandebele. Journal of Southern African Studies 41(5).

\section{Case Law}

20120220 Baphalane ba Ramokoka Community and Others v Minister of Agriculture and Land Affairs and Others (LCC 09/2007, unreported)

\section{Legislation}

Natives Land Act (Act 27 of 1913)

Restitution of Land Rights Act (Act 22 of 1994)

Constitution of the Republic of South Africa (Act 108 of 1996)

Restitution of Land Rights Amendment Act (Act 15 of 2014)

Olaf Zenker is Junior Professor at the Institute of Social and Cultural Anthropology, Freie Universität Berlin. His recent publications include Transition and Justice: Negotiating the Terms of New Beginnings in Africa (2015), Irish/ness Is All Around Us: Language Revivalism and the Culture of Ethnic Identity in Northern Ireland (2013) and Beyond Writing Culture: Current Intersections of Epistemologies and Representational Practices (2010). 